\title{
STUDI KARAKTERISTIK HIDRODINAMIKA KAPAL IKAN TRADISIONAL DI PERAIRAN PUGER JEMBER
}

\section{HYDRODYNAMICS CHARACTERISTIC STUDY OF THE TRADITIONAL FISHING VESSEL IN PUGER JEMBER WATERS}

\author{
Hery Indria Dwi Puspita ${ }^{1)}$ dan I Ketut Aria Pria Utama ${ }^{2)}$ \\ 1) Jurusan Teknik Mesin, Fakultas Teknik-UNEJ, Jember \\ ${ }^{2)}$ Jurusan Teknik Perkapalan, Fakultas Teknologi Kelautan-ITS, Surabaya \\ e-mail : heryindria.dwipuspita@gmail.com \\ Diterima tanggal: 14 Desember 2016 ; diterima seletal perbaikan: 7 Maret 2017 ; Disetujui tanggal: 6 April 2017
}

\begin{abstract}
ABSTRAK
Secara umum, kapal ikan tradisional digunakan oleh nelayan di Indonesia dalam berlayar untuk menangkap ikan terutama nelayan di Kecamatan Puger, Jember. Pengrajin kapal ikan tradisional di Puger pada dasarnya hanya memodifikasi dari desain kapal sebelumnya dengan dasar keterampilan yang didapatkan dari turun-temurun pendahulunya. Karena kapal ikan tradisional di Puger tidak melalui proses formal dalam pembangunan kapal, maka diperlukan studi karakteristik hidrodinamika kapal ikan tradisional. Studi karakteristik hidrodinamika kapal ikan tradisional ini bertujuan untuk mengetahui kemampuan kapal bertahan dalam kondisi berbahaya saat beroperasi. Metode yang digunakan adalah dengan mengukur secara langsung dimensi utama dan mengukur bentuk body dari tiga kapal ikan tradisional di perairan Puger Jember. Selanjutnya hasil pengukuran tersebut digambar kembali, dan kemudian dilakukan evaluasi resistance dan seakeeping kapal ikan tradisional Puger Jember. Berdasarkan hasil evaluasi resistance dengan berbagai variasi kecepatan, kapal ikan tradisional di Puger Jember dengan lambung berbentuk lebih gemuk memiliki resistance yang lebih besar. Kemudian, dari evaluasi seakeeping ketiga kapal memiliki kriteria gerakan heave, pitch, dan roll yang berbeda-beda sesuai dengan bentuk body kapal.
\end{abstract}

Kata kunci: Hidrodinamika, kapal ikan tradisional, Puger Jember, resistance, seakeeping.

\section{ABSTRACT}

In general, traditional fishing vessels are used to by fisherman in Indonesia especially fisherman to catch fish in Puger district, Jember. Traditional fishing vessel makers in Puger basically only modified from the ship design in the past using a base skills that obtained from hereditary its predecessor. Because traditional fishing vessel in Puger have not formal process on build ship, so hydrodynamics characteristic study of the traditional fishing vessel is needed. Hydrodynamics characteristic study of the traditional fishing vessel has purpose to understanding the ability of a ship stable stay in a dangerous condition during operation. Method used is by measuring directly the primary dimension and also measure the shape of the three traditional fishing vessel body in the Puger-Jember waters. Furthermore, the result of these measurements can be redrawn, and then evaluated the resistance and seakeeping of the traditional fishing vessel. Based on the evaluation of resistance with a variety speed, the traditional ship with fatter shaped hull has greater resistance. Then, based on the seakeeping evaluation are discovered the three ship have heave, pitch, and roll movements criteria which different according to the form body a ship.

Keywords: Hydrodynamics, traditional fishing vessel, Puger Jember, resistance, seakeeping. 


\section{PENDAHULUAN}

Kapal ikan tradisional pada umumnya digunakan oleh nelayan di Kecamatan Puger Kabupaten Jember dalam berlayar untuk menangkap ikan. Para pengrajin kapal ikan tradisional di Puger pada dasarnya hanya memodifikasi dari desain kapal sebelumnya dengan dasar keterampilan yang didapatkan dari turuntemurun pendahulunya. Karena kapal ikan tradisional di Puger tidak melalui proses formal dalam pembangunan kapal, keamanan berlayar dari kapal ikan tersebut saat beroperasi masih dipertanyakan.

Kapal ikan merupakan kapal yang digunakan khusus untuk melakukan penangkapan ikan, pengangkutan ikan, dan lain-lain. Kapal ikan dapat dibedakan menjadi dua, yaitu kapal penangkap ikan dan kapal bukan penangkap ikan. Kapal penangkap ikan merupakan kapal yang secara khusus dipergunakan untuk menangkap ikan, termasuk menampung, menyimpan, mendinginkan, atau mengawetkan, sedangkan kapal bukan penangkap ikan atau kapal pengangkut ikan merupakan kapal yang secara khusus dipergunakan untuk mengangkut ikan, termasuk juga memuat, menampung, menyimpan, mendinginkan, atau mengawetkan (Siombo, 2010). Kapal ikan yang banyak digunakan oleh nelayan di Puger Kabupaten Jember adalah kapal ikan tradisional. Kapal ikan tradisional di Puger pada umumnya berbahan dasar kayu dengan alat tangkap berupa jaring payang. Satu kali berlayar nelayan biasanya mendapatkan \pm 2 ton ikan berupa ikan jenis tongkol, dan ada beberapa jenis ikan lain.

Kapal ikan tradisional biasanya dioperasikan oleh nelayan dengan jangkauan wilayah perairan yang tidak terlalu jauh atau masih di sekitar pinggir pantai, begitu pula dengan penangkapannya tak sebesar kapal ikan modern. Para pengrajin kapal ikan tradisional di Puger pada dasarnya hanya memodifikasi dari desain kapal sebelumnya dengan dasar keterampilan yang didapatkan dari turun-temurun pendahulunya. Karena tidak ada proses formal dalam pembangunan kapal ikan maka diperlukan studi karakteristik hidrodinamika kapal ikan tradisional di perairan Puger Jember. Mendesain kapal, ukuran utama kapal dan garis bentuk lambung kapal perlu diatur untuk mengoptimalkan bentuk lambung kapal agar kinerjanya lebih baik dari segi keamanan dan efisien kapal pada saat beroperasi (Kim et al., 2017).

Cara pembuatan kapal ikan tradisional lebih mengandalkan "insting" dari para pengrajin kapal ikan yang cenderung menghasilkan produk dengan ciri culture-based daripada technology-based product. Meskipun hal tersebut merupakan warisan yang perlu dilestarikan, namun kelemahan yang dimiliki oleh rancangan kapal tradisional perlu mendapatkan prioritas, tanpa meninggalkan sisi tradisi secara revolusioner. Selain itu, karakteristik dari bentuk lambung kapal ikan tradisional di Puger yang memiliki bentuk yang gemuk dan lebar yang menjadi ciri khas dari kapal ikan di Puger, dengan kata lain bentuk lambung yang gemuk dan lebar tersebut dapat menambah hambatan yang dialami. Nilai hambatan yang besar akan mempengaruhi dari kecepatan kapal saat beroperasi. Semakin besar hambatannya maka kecepatan kapal saat beroperasi akan semakin kecil atau berkurang. Studi karakteristik hidrodinamika kapal bertujuan untuk mengetahui kemampuan kapal bertahan dalam kondisi berbahaya saat beroperasi. Serta, tujuan dari penelitian ini adalah untuk mendapatkan nilai hambatan dan seakeeping dari kapal ikan tradisional Puger. Sehingga, nilai tersebut dapat digunakan untuk mengetahui kelemahan atau kekurangan dari kapal ikan tradisional Puger. Hasil dari penelitian ini dapat digunakan sebagai rekomendasi untuk perbaikan desain kapal ikan tradisional Puger, serta dapat memberikan informasi mengenai kapal ikan tradisional yang memiliki kualitas hidrodinamika yang lebih baik atau sesuai dengan perairan Puger dari segi hambatan dan seakeeping, sehingga mampu meningkatkan faktor keselamatan nelayan pada saat berlayar dan menangkap ikan.

Teori gerak kapal sudah banyak dikembangkan pada awal abad ke-20. Hal tersebut ditunjukkan dengan adanya metode perhitungan koefisien massa tambah dan redaman hidrodinamis untuk benda dua dimensi maupun benda tiga dimensi yang terapung. Kemajuan teori tersebut telah dilakukan dalam sejumlah penelitian, antara lain, Lewis (1929) dan Haskind (1946) telah meningkatkan ketelitian hipotesis Froude-Krylov dengan mempertimbangkan gangguan benda terapung pada medan tekanan gelombang insiden, atau fenomena radiasi. Korvin-Kroukovsky (1955) dan KorvinKroukovsky \& Jacobs (1957) menerapkan konsep gerakan relatif dalam memecahkan masalah difraksi atau refleksi gelombang insiden akibat keberadaan benda.

Gerakan osilasi bangunan apung akibat eksistasi gelombang terdiri dari 6-derajat kebebasan. Mode gerakan osilasi terdiri dari mode gerakan translasional pada arah sumbu sumbu x, y, dan z yaitu surge, sway, dan heave, serta mode gerakan rotational terhadap ketiga sumbu $\mathrm{x}, \mathrm{y}$, dan $\mathrm{z}$ yaitu roll, pitch, dan yaw 


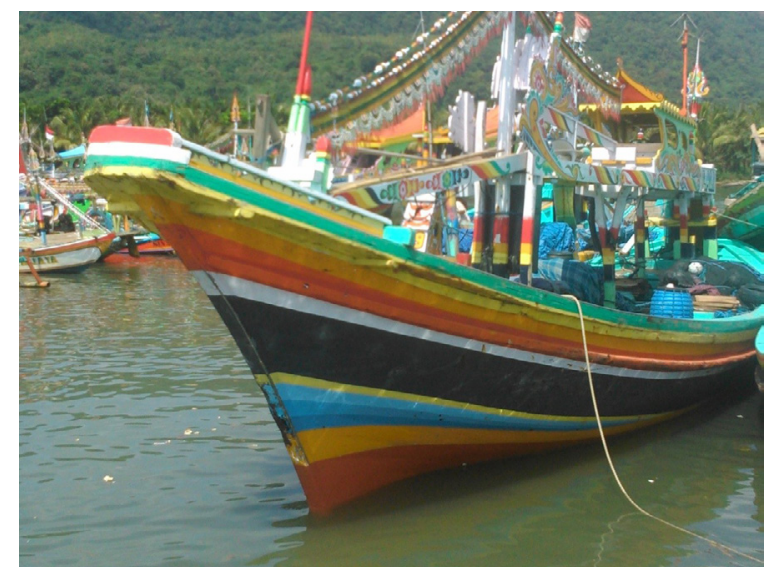

Gambar 1. Kapal ikan tradisional di Puger.

Figure 1. Traditional fishing ships in Puger.

(Djatmiko, 2012). Gerakan translasional merupakan gerakan benda atau kapal yang sejajar dengan sumbu yang diacu. Surging adalah gerakan osilasi translasional dari benda atau kapal pada arah sumbu x (majumundur), swaying adalah gerakan translasi dari benda atau kapal pada arah sumbu y (melintang), dan heave adalah gerakan osilasi translasional dari suatu struktur terapung pada arah sumbu vertikal (sumbu-z). Sedangkan, gerak rotasional merupakan gerakan putaran benda apung dimana sumbu acuan menjadi porosnya. Gerakan roll merupakan gerakan rotasi benda apung yang berporos pada sumbu $\mathrm{x}$, gerakan pitch merupakan gerakan rotasi benda apung yang berporos pada sumbu y, dan gerakan yaw merupakan gerakan rotasi benda apung yang berporos pada sumbu z (Kroukovsky \& Jacobs, 1957) (Bhattacarya, 1978).

Langkah awal dalam penelitian ini yaitu perlu adanya survei atau pengambilan data untuk mendapatkan data dimensi atau ukuran utama kapal, data bentuk lambung kapal ikan, data geografis, data jarak pelayaran, data jumlah tangkapan, dan jenis alat tangkap. Selanjutnya dari ukuran lambung kapal yang didapatkan, dilakukan pemodelan dengan ukuran data kapal yang sebenarnya. Kemudian, dari model kapal tersebut dilakukan evaluasi hambatan dan seakeeping. Setelah itu, hasil evaluasi hambatan dan seakeeping tersebut dibandingkan sehingga didapatkan kesimpulan bentuk lambung yang memiliki karakteristik hambatan dan seakeeping yang lebih baik dan sesuai dengan kondisi di perairan Puger. Hal ini dapat memperbaiki dan menambah performa dari kapal ikan tersebut dan memberikan rekomendasi untuk perbaikan desain kapal ikan tradisional di perairan Puger Kabupaten Jember.

\section{BAHAN DAN METODE}

Studi karakteristik hidrodinamika kapal ikan tradisional diperlukan untuk memenuhi kapasitas daripada faktor keamanan dan hidrodinamika. Karakteristik hidrodinamika tersebut meliputi hambatan dan seakeeping.

Dibawah ini dibahas lebih lanjut mengenai langkah-langkah dalam pengerjaan penelitian.

\section{Pengumpulan Data}

Data yang dikumpulkan didapatkan dari wawancara langsung, pengukuran, dan pengamatan di lapangan. Dalam penelitian ini, diambil tiga kapal yang akan dievaluasi.

\section{Penggambaran Model Lambung}

Penggambaran model yang dilakukan untuk evaluasi berdasarkan data dari hasil survei bentuk lambung kapal ikan tipe perairan Puger yang dibuat dengan pengadaptasi bentuk lambung kapal ikan yang telah ada. Ada tiga hal perlu diperhatikan dalam mendesain kapal yaitu displacement, luas permukaan basah lambung kapal atau wetted surface area (WSA), rasio L/B (Markwood, 2010).

\section{Evaluasi Hambatan}

Hambatan kapal adalah gaya hambat yang bekerja pada kapal dari media fluida yang arah gayanya berlawanan dengan gerakan kapal saat melaju pada kecepatan tertentu. Gaya dorong (thrust) untuk mendorong kapal dibutuhkan karena adanya hambatan. Pada saat berlayar kapal akan mengalami beberapa hambatan akibat dari interaksi antara kapal dengan fluida atau air laut (Harvald, 1983). Hambatan-hambatan 

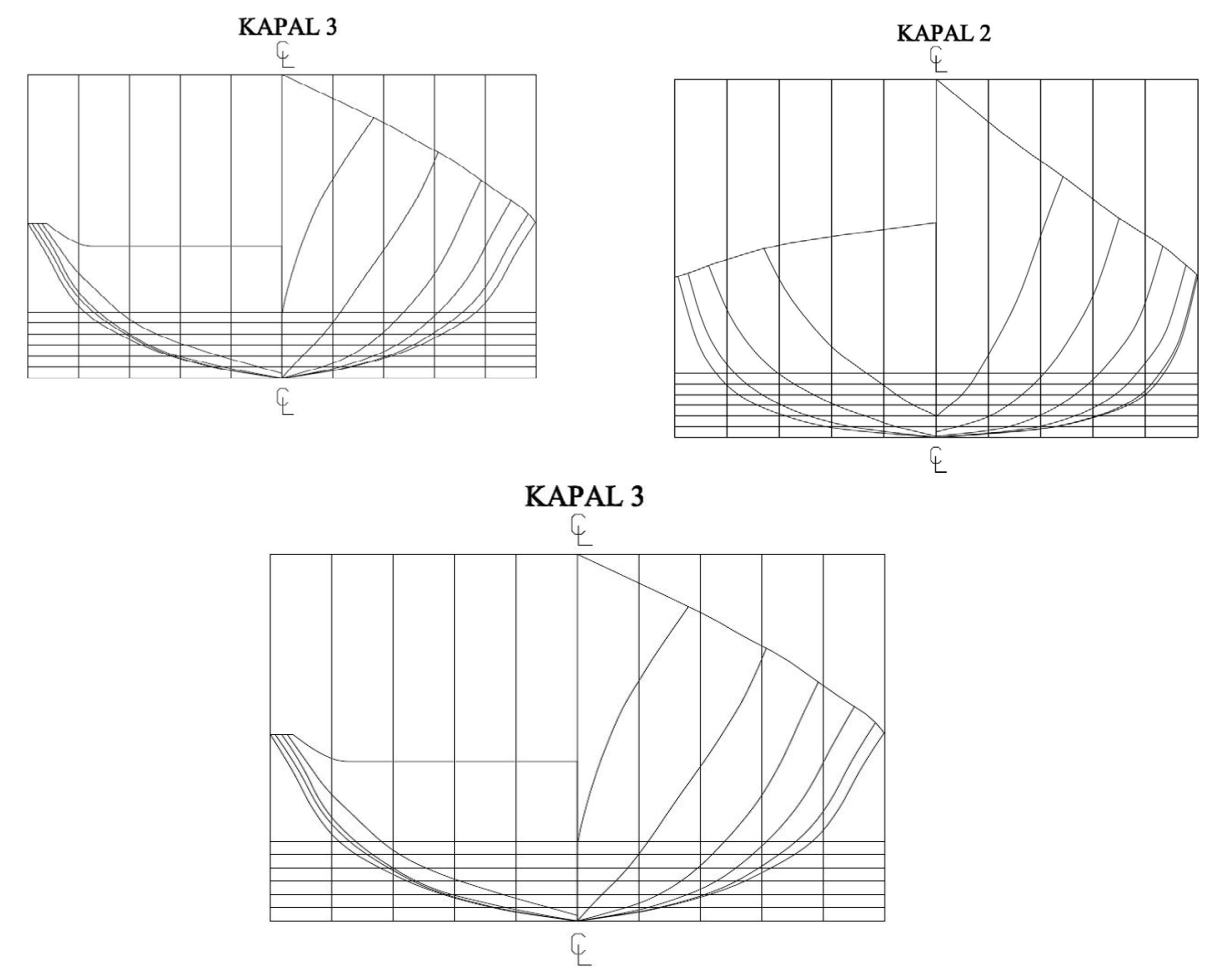

Gambar 2. Bodyplan dari lambung ketiga kapal ikan tradisional di Puger.

Figure 2. The third hull bodyplan of traditional fishing ships in Puger.

tersebut meliputi hambatan gelombang, hambatan viskos, dan hambatan gesek. Hambatan ditransmisikan ke lambung sebagai distribusi tekanan dan gaya geser, tegangan geser ditimbulkan karena adanya viskositas dari air. Hambatan total dilambangkan dengan $\mathrm{R}_{\mathrm{T}}$. Hambatan total dapat dihitung menggunakan rumus sebagai berikut (Molland et al., 2011):

$$
R_{T}=0.5 \times \rho \times C_{T} \times W S A \times V_{S}^{2}
$$

$$
\text { dimana: }
$$

$\mathrm{R}_{\mathrm{T}}=$ hambatan total

$\rho=$ massa jenis air laut $\left(1,025 \mathrm{ton} / \mathrm{m}^{3}\right)$

$\mathrm{C}_{\mathrm{T}}=$ koefisien hambatan total

WSA $=$ luas permukaan basah $($ WSA $)\left(\mathrm{m}^{3}\right)$
$\mathrm{V}_{\mathrm{S}}=$ kecepatan kapal (knot)

Hambatan kapal adalah gaya hambat yang bekerja pada kapal dari media fluida yang arah gayanya berlawanan dengan gerakan kapal saat melaju pada kecepatan tertentu. Evaluasi hambatan dalam penelitian dilakukan dengan menggunakan metode numerik Computational Fluid Dynamics (CFD).

\section{Evaluasi Seakeeping}

Seakeeping yaitu perilaku gerak kapal dipengaruhi oleh gaya-gaya dari luar yang disebabkan oleh kondisi gelombang. Evaluasi seakeeping untuk melihat gerak

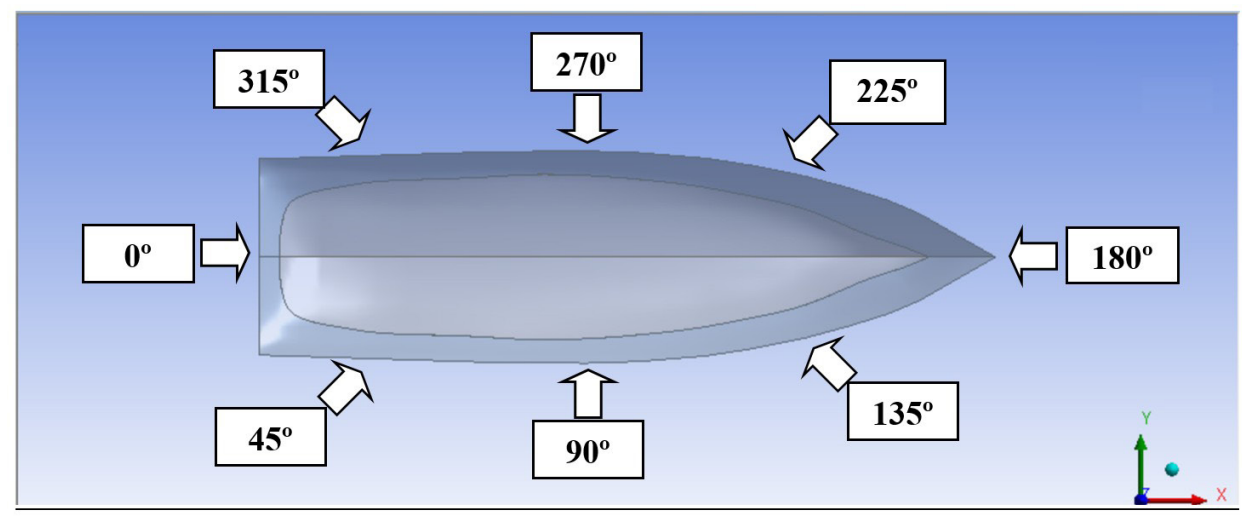

Gambar 3. Sudut datang gelombang

Figure 3. The wave coming direction 
kapal akibat arah gelombang yang datang pada badan kapal dengan menganalisa kriteria gerakan heave, pitch, dan roll. Hasil prediksi gerakan bangunan apung umumnya diberikan dalam bentuk perbandingan antara amplitudo mode gerakan tertentu dengan amplitudo gelombang insiden, yang berfungsi sebagai fungsi perubahan frekuensi gelombang. Perbandingan amplitudo disebut sebagai Response Amplitudo Operator (RAO). RAO disebut juga dengan transfer function yang merupakan fungsi respons gerakan dinamis suatu benda apung yang disebabkan oleh gelombang dengan rentang frekuensi tertentu. RAO merupakan alat untuk mentransfer gaya gelombang menjadi respons gerakan dinamis struktur (Chakrabarti, 1987).

Persamaan RAO dapat dihitung dengan rumus sebagai beri

$$
R A O=\frac{\left|\eta_{j}\right|}{\varsigma_{a}}
$$

$\left|\eta_{j}\right|$ limana:

= amplitudo gerakan kapal, dalam enam derajat

ke $\varsigma_{a}$ asan, dalam hal ini adalah heave, pitch, dan roll. = amplitudo gelombang

Menurut teori klasik gerakan kapal diatas gelombang reguler secara matematis dapat diformulasikan dengan mengacu pada hukum Newton ke-2 (Froude, 1861) (Krylov, 1896). RAO merupakan rasio dari amplitudo gerakan kapal dalam enam derajat kebebasan dan amplitudo gelombang. Evaluasi seakeeping digunakan untuk melihat gerakan kapal yang disebabkan oleh gelombang dating pada body kapal dengan menganalisa kriteria gerakan heave, pitch, dan roll.

\section{Penarikan Kesimpulan}

Kesimpulan berupa analisis hambatan kapal dan analisis seakeeping dari ketiga kapal. Sehingga dapat ditentukan bentuk lambung mana yang memiliki peforma lebih baik dengan tujuan dapat merekomendasikan perbaikan desain kapal ikan tradisional di Puger. Kesimpulan dibuat untuk mengetahui hambatan dan seakeeping dari ketiga kapal.

\section{HASIL DAN PEMBAHASAN}

Berdasarkan hasil survei, diperoleh informasi ukuran utama untuk ketiga tipe kapal di Puger. Tabel 1 menunjukkan dimensi dari tiga tipe kapal ikan di Puger, dan Tabel 2 menunjukkan nilai WSA (wetted surface area/luas permukaan basah lambung kapal) dan $\mathrm{Cb}$ (koefisien blok) dari ketiga kapal ikan di Puger.
Dari Tabel 2 menunjukkan nilai WSA terbesar adalah kapal-2 dan yang memiliki nilai WSA terkecil adalah kapal-1. Kemudian, Gambar 2 menunjukkan bodyplan dari ketiga kapal ikan di Puger. Dari Gambar 2 dapat diketahui bentuk dari ketiga lambung ikan tradisional di Puger, sehingga dapat menggambarkan bentuk lambung dari ketiga ikan tradisional Puger.

Hasil evaluasi dari hambatan kapal ikan tradisional di Puger dapat dilihat pada Tabel 3. Tabel 3 menunjukkan hubungan antara kecepatan dengan hambatan kapal dari ketiga model kapal ikan di Puger pada kecepatan 5 knot sampai 10 knot. Pada Tabel 3 dapat dilihat bahwa hambatan berbanding lurus dengan kecepatan. Semakin besar kecepatan maka semakin besar pula hambatannya. Terlihat pada Tabel 3, kapal yang memiliki nilai hambatan paling besar adalah kapal-2, selanjutnya kapal-3, dan yang paling kecil hambatannya adalah kapal-1. Pada Tabel 2, nilai WSA yang lebih besar menjadi salah satu faktor yang mempengaruhi besarnya hambatan yang terjadi pada kapal-2. Selain itu, faktor yang mempengaruhi besarnya hambatan kapal adalah nilai rasio L/B kapal-2 yang lebih kecil yaitu 3,170 dibandingkan dengan kapal-1 dan kapal-3 yaitu 3,966 dan 3,936. Karena, rasio L/B dapat menambah hambatan kapal. Sedangkan, untuk kapal-1 memiliki nilai hambatan yang lebih kecil (Schneekluth \& Betram, 1998). Dilihat dari ukuran utamanya kapal-1 memiliki dimensi yang lebih kecil dari yang lainnya, sehingga kapal-1 memiliki nilai hambatan yang lebih kecil.

Hasil dari evaluasi seakeeping berupa plot grafik antara encounter wave frequency dengan RAO atau rasio dari amplitudo gerakan kapal dalam enam derajat kebebasan dan amplitudo gelombang. Gambar 3 menunjukkan sudut datang dari gelombang. Gambar 3 menggambarkan sudut datang yang digunakan dalam penelitian ini. Karakteristik hidrodinamika suatu kapal diketahui melalui analisa dalam bentuk karakteristik gerakan-gerakan kapal pada saat berlayar. Karakteristik gerakan tersebut akan disajikan dalam bentuk gerakangerakan heave, pitch, dan roll pada sudut heading $90^{\circ}$, $135^{\circ}$, dan $180^{\circ}$.

Pada Gambar 4 yang menunjukkan mode gerakan heave, RAO maksimum terjadi di kapal-3 pada sudut datang gelombang $90^{\circ}$ dengan nilai $1,148 \mathrm{~m} / \mathrm{m}$ pada frekuensi 2,644 rad/s yang ditunjukkan dengan garis putus-titik hitam. Pada Gambar 4 menunjukkan kurva untuk kapal-3 pada sudut $90^{\circ}$ yang dari nilai RAO 1 $\mathrm{m} / \mathrm{m}$ kemudian pada frekuensi $1 \mathrm{rad} / \mathrm{s}$ nilai RAO mulai meningkat sampai 2,644 rad/s dengan nilai maksimum 
Tabel 1. Ukuran utama kapal ikan di Puger Jember

Table 1. Main size of fishing ship in Puger Jember

\begin{tabular}{lccc}
\hline Nama Kapal & PanjangLebar & Tinggi & Sarat \\
\hline Kapal-1 13 m & $3,5 \mathrm{~m}$ & $1,5 \mathrm{~m}$ & $0,5 \mathrm{~m}$ \\
Kapal-2 15 m & $5 \mathrm{~m}$ & $1,5 \mathrm{~m}$ & $0,6 \mathrm{~m}$ \\
Kapal-3 16 m & $4,6 \mathrm{~m}$ & $1,4 \mathrm{~m}$ & $0,6 \mathrm{~m}$ \\
\hline
\end{tabular}

Tabel 2. WSA dan $\mathrm{Cb}$

Table 2. WSA and $\mathrm{Cb}$

\begin{tabular}{llll}
\hline & Kapal-1 & Kapal-2 & Kapal-3 \\
\hline WSA $\left(\mathbf{m}^{2}\right)$ & 27,528 & 46,222 & 38,473 \\
Cb & 0,468 & 0,472 & 0,477 \\
\hline
\end{tabular}

Tabel 3. Hambatan total terhadap kecepatan

Table 3. Total resistance force to speed

\begin{tabular}{llll}
\hline Kecepatan & Kapal-1 & Kapal-2 & Kapal-3 \\
\cline { 2 - 4 } & Hambatan & Hambatan & Hambatan \\
\hline 5 knot & $0,696 \mathrm{kN}$ & $1,590 \mathrm{kN}$ & $1,525 \mathrm{kN}$ \\
$6 \mathrm{knot}$ & $1,250 \mathrm{kN}$ & $2,800 \mathrm{kN}$ & $2,304 \mathrm{kN}$ \\
$7 \mathrm{knot}$ & $1,862 \mathrm{kN}$ & $3,989 \mathrm{kN}$ & $3,293 \mathrm{kN}$ \\
$8 \mathrm{knot}$ & $2,667 \mathrm{kN}$ & $5,759 \mathrm{kN}$ & $5,143 \mathrm{kN}$ \\
$9 \mathrm{knot}$ & $4,156 \mathrm{kN}$ & $7,693 \mathrm{kN}$ & $7,217 \mathrm{kN}$ \\
$10 \mathrm{knot}$ & $8,056 \mathrm{kN}$ & $10,238 \mathrm{kN}$ & $10,110 \mathrm{kN}$ \\
\hline
\end{tabular}

$1,148 \mathrm{~m} / \mathrm{m}$ yang menunjukkan nilai RAO maksimum untuk gerakan heave. Hal ini memberikan informasi yang dapat digunakan acuan oleh operator, yaitu jika pada saat berlayar kapal-3 menghadapi gelombang yang relatif besar yang mengarah pada sudut $90^{\circ}$ maka dapat diupayakan untuk bermanuver. Intensitas gerakan heave lebih didominasi oleh gelombang sisi atau sudut $90^{\circ}$.

Pada Gambar 5 gerakan pitch, RAO maksimum terjadi di kapal-1 pada sudut datang $180^{\circ}$ dengan nilai 1,290 $\mathrm{deg} / \mathrm{m}$ pada frekuensi $1,796 \mathrm{rad} / \mathrm{s}$ yang ditunjukkan dengan garis hitam. Pada Gambar 5 menunjukkan kurva untuk kapal-1 pada sudut datang $180^{\circ}$ yang dari nilai RAO 0,082 deg/m kemudian meningkat sampai nilai maksimum $1,290 \mathrm{deg} / \mathrm{m}$ yang menunjukkan nilai RAO maksimum untuk gerakan pitch pada frekuensi $1,796 \mathrm{rad} / \mathrm{s}$. Intensitas gerakan pitch lebih didominasi oleh gelombang haluan atau sudut $180^{\circ}$.

Pada Gambar 6 gerakan roll, RAO maksimum terjadi di kapal-3 pada sudut datang $90^{\circ}$ dengan nilai 6,614 $\mathrm{deg} / \mathrm{m}$ pada frekuensi 2,522 $\mathrm{rad} / \mathrm{s}$. Pada Gambar 6 menunjukkan kurva untuk kapal-3 pada sudut $90^{\circ}$ yang dari nilai RAO 1,01 deg/m kemudian meningkat sampai nilai maksimum $6,614 \mathrm{deg} / \mathrm{m}$ yang menunjukkan nilai RAO maksimum untuk gerakan roll pada frekuensi 2,522 rad/s. Gambar 6 menunjukkan kapal-1, kapal-2, dan kapal-3 dalam propagasi gelombang haluan atau sudut $180^{\circ}$ terjadi gerakan roll yang sangat kecil, secara teoriris diharapkan gerakan roll tidak akan terjadi. Intensitas gerakan roll lebih didominasi oleh gelombang sisi atau sudut $90^{\circ}$. Berdasarkan tinjauan terhadap gerakan ketiga model kapal ikan tradisional Puger di gelombang regular, pada dasarnya dapat dikatakan mempunyai kualitas yang cukup baik, tidak ada intensitas gerakan yang berlebihan. Secara umum, dilihat dari gerakan heave, pitch, dan roll kapal 2 terlihat lebih baik dibandingkan kedua kapal yang lainnya, meskipun pada gerakan roll dengan sudut $90^{\circ}$ terjadi kenaikan. Ini dikarenakan intensitas gerakan roll lebih didominasi oleh gelombang sudut $90^{\circ}$, sehingga jika ada gelombang yang mengarah ke bagian sisi kapal maka akan terjadi mode gerakan roll yang lebih tinggi.

Berdasarkan evaluasi hambatan dan seakeeping, dapat diambil kesimpulan bahwa dari segi hambatan, kapal-2 memiliki nilai hambatan yang cukup besar tetapi pada dari segi seakeeping kapal 2 memiliki kualitas yang cukup baik pada gerakan heave, pitch 
dan roll dibandingkan kedua kapal yang lain. Jika, dibandingkan dengan tiga kapal ikan di Puger, kapal-1 mempunyai karakteristik hambatan yang tidak terlalu besar dan nilai RAO yang tidak terlalu tinggi pada kondisi tertentu, sehingga dapat dikatakan bahwa kapal-1 memiliki karakteristik yang cukup baik dari kedua kapal ikan Puger. Kedepannya desain kapal-1 dapat dikembangkan untuk mendapatkan karakteristik hidrodinamika yang baik yang sesuai dengan kondisi perairan Puger. Sedangkan untuk kapal-2 dapat di desain ulang hingga mendapatkan nilai hambatan yang baik, dengan tidak banyak merubah nilai kualitas seakeeping yang terbukti dalam penelitian ini sudah memiliki kualitas yang baik.

\section{KESIMPULAN DAN SARAN}

\section{Kesimpulan}

Pada paper ini dibahas mengenai Studi karakteristik hidrodinamika yaitu untuk mendapatkan nilai hambatan dan seakeeping dari ketiga kapal ikan tradisional di Puger. Dapat ditarik kesimpulan bahwa kapal-1 dengan panjang $13 \mathrm{~m}$ dan lebar 3,5 m, yang memiliki nilai hambatan yang tidak terlalu besar, dan nilai kualitas seakeeping yang cukup baik sehingga dapat digunakan sebagai acuan untuk desain ulang kapal-1 hingga dapat memberikan performa kapal ikan tradisional yang lebih baik. Kapal-2 dengan panjang 15 $\mathrm{m}$ dan lebar $5 \mathrm{~m}$, memiliki nilai hambatan yang cukup besar tetapi pada dari segi seakeeping kapal-2 memiliki kualitas yang cukup baik. Sehingga, kapal-2 dapat di desain ulang hingga mendapatkan nilai hambatan yang baik, dengan tidak banyak merubah nilai kualitas seakeeping. Hasil diatas dapat digunakan sebagai acuan untuk memberikan rekomendasi perbaikan untuk desain kapal ikan tradisional yang lebih sesuai di perairan Puger Kabupaten Jember. Desain tersebut mampu meningkatkan faktor keselamatan nelayan saat berlayar dalam menangkap ikan.

\section{Saran}

Disarankan untuk penelitian selanjutnya yaitu dapat menambahkan evaluasi stabilitas sehingga penelitian ini dapat menjadi lebih lengkap dan lebih berguna bagi pengembangan kapal ikan tradisional di perairan Puger serta dapat lebih meningkatkan faktor keselamatam nelayan pada saat berlayar dan menangkap ikan.

\section{DAFTAR PUSTAKA}

Bhattacarya, R. (1978). Dynamics of Marine Vehicles. John Wiley \& Sons: New York.

Chakrabarti, S. K. (1987). Hydrodynamics of Offshore Structures. Computational Mechanics Publications: Southampton.

Djatmiko, E. B. (2012). Perilaku dan Operabilitas Bangunan Laut di Atas Gelombang Acak. ITS Press: Surabaya.

Faltinsen, O. M. (2005). Hydrodynamics of High-Speed Marine Vehicles. Cambridge University Press: Cambridge.

Froude, W. (1861). On the Rolling of Ships. Transactions of INA. vol. 2.

Harvald, S. A. (1983). Resistance and Propulsion of Ships. Wiley Interscience: New York.

Haskind, M. D. (1946). The Hydrodynamic Theory of a Ship in Rolling and Pitching. Technical Reseacrch Bulletin. no. 1-12: 3-43.

Kim, M., Hizir, O., Turan, O., Day, S., \& Incecik, A. (2017). Estimation of Added Resistance and Ship Speed Loss in a Seaway. Elsevier. pp. 1-12.

Korvin-Kroukovsky, B. V. (1955). Investigation of Ship Motions in Regular Waves. Transactions of SNAME. vol. 63: 386-435.

Kroukovsky, B. V. K., \& Jacobs, W. R. (1957). Pitching and Heaving Motions of a Ship in Regular Waves. Transactions of SNAME. vol. 63: 590-632.

Krylov, A.N. (1896). A New Theory of the Pitching Motion of Ships on Waves and of the Stresses Produced by This Motion. Transactions of INA. vol. 37.

Lewis, F. M. (1929). The Inertia of Water Surrounding a Vibrating Ship. Transactions of SNAME. vol. 37: $1-20$.

Markwood, C. H. (2010). Hull Cross Sections for Multihulls. Mulitihull Dynamics Inc: French.

Molland, A. F., Turnock, S. R., \& Hudson, D. A. (2011). Ship Resistance and Propulsion. Cambridge University Press: Cambridge.

Schneekluth, H., \& Bertram, V. (1998). Ship Design for Efficiency and Economy. Butterworth-Heinemann: Oxford.

Siombo, M. R. (2010). Hukum Perikanan Nasional dan Internasional. Gramedia: Jakarta. 
